\title{
Physicochemical analysis of casein solubility in water-ethanol solutions
}

\author{
Samir MEZDOUR ${ }^{\mathrm{a}}$, Gérard BRULÉb ${ }^{\text {, Józef KOROLCZUK }}{ }^{\mathrm{b} *}$ \\ a École Nationale Supérieure des Industries Agricoles et Alimentaires, 1 avenue des Olympiades, \\ F-91744 Massy cedex, France \\ b INRA-Agrocampus Rennes, UMR1253 Science et Technologie du Lait et de l'CEuf, \\ 65 rue de Saint-Brieuc, F-35042 Rennes cedex, France \\ Received 16 July 2006 - Accepted 24 November 2006
}

\begin{abstract}
Due to the change in the apparent acid dissociation constant, when ethanol was added to water solutions of an industrially produced spray-dried sodium caseinate, the solution's $\mathrm{pH}$ increased proportionally to the reciprocal relative dielectric constant $(1 / \varepsilon)$. The $\mathrm{pH}$ increased by 1 unit when the ethanol volume fraction reached about 0.60 . The casein solubility profile at $20^{\circ} \mathrm{C}$ as a function of $\mathrm{pH}(3-8)$ and the ethanol volume fraction (0-0.75) was quite well represented by the equation describing the ionisation process. The $\mathrm{pH}$ inflection point and the slope coefficient were approximately linearly related to $1 / \varepsilon$. The evolution of the electrostatic surface potential $\left(\psi_{0}\right)$ and the zeta potential $(\zeta)$ explained the changes in casein solubility as a function of $\mathrm{pH}$ and the dielectric constant of the solvent. The increase in $\psi_{0}$ by $37 \pm 5.2 \mathrm{mV}$ or in $\zeta$ by $8.6 \pm 1.4 \mathrm{mV}$ raised casein solubility from 10 to $90 \%$.
\end{abstract}

casein / solubility / ethanol / dielectric constant / electrostatic potential

摘要 - 水一乙醇溶液中酪蛋白溶解性的理化分析。将乙醇加入到由喷雾干燥生产的酪蛋白 酸钠水溶液后, 由于表观酸离解常数的变化, 溶液的 $\mathrm{pH}$ 增加与介电常数的倒数 $(1 / \varepsilon)$ 成正 比。当加入乙醇的体积分数达到 0.6 时, 溶液的 $\mathrm{pH}$ 增加了 1 个单位。在 $20^{\circ} \mathrm{C}$ 时, 酪蛋白 的溶解性与 $\mathrm{pH}(3-8)$ 和乙醇体积分数 $(0-0.75)$ 之间的函数关系可以很好地用电离方程描述。 $\mathrm{pH}$ 拐点和斜率系数与 $1 / \varepsilon$ 基本上呈线性关系。表面静电势 $\left(\psi_{0}\right)$ 和zeta电势 $(\zeta)$ 的变化进程可以 很好地解释酪蛋白的溶解性与 $\mathrm{pH}$ 和溶剂的介电常数之间函数变化。当 $\psi_{0}$ 增加到 $37 \pm 5.2 \mathrm{mV}$ 或者 $\zeta$ 增加到 $08.6 \pm 1.4 \mathrm{mV}$, 酪蛋白的溶解性由 $10 \%$ 增加达到 $90 \%$ 。

酪蛋白 / 溶解性 / 乙醇 / 介电常数 / 静电势

Résumé - Analyse physicochimique de la solubilité de la caséine dans des solutions d'éthanoleau. En raison du changement de la constante apparente de la dissociation acide, l'ajout d'éthanol aux solutions aqueuses d'un caséinate de sodium industriel séché par pulvérisation, provoque une augmentation du $\mathrm{pH}$ des solutions inversement proportionnelle à la constante diélectrique $(1 / \varepsilon)$. Le $\mathrm{pH}$ augmente d'une unité quand la fraction volumique d'éthanol atteint environ 0.6 . Le profil de la solubilité de la caséine à $20^{\circ} \mathrm{C}$, pour des $\mathrm{pH}$ de 3 à 8 et pour la fraction volumique d'éthanol entre 0 et 0.75 , est assez bien représenté par une équation qui décrit le processus d'ionisation. Le point d'inflexion et la pente sont approximativement linéairement liés à $1 / \varepsilon$. L'évolution du potentiel électrostatique de surface $\left(\psi_{0}\right)$ et du potentiel zeta $(\zeta)$ explique les changements de la solubilité de la caséine en fonction du $\mathrm{pH}$ et de la constante diélectrique du solvant. L'augmentation du $\psi_{0}$ de $37 \pm$ $5.2 \mathrm{mV}$ ou du $\zeta$ de $8.6 \pm 1.4 \mathrm{mV}$ élève la solubilité de la caséine de 10 à $90 \%$.

caséine / solubilité / éthanol / constante diélectrique / potentiel électrostatique

* Corresponding author (通讯作者): jozef.korolczuk@gmail.com 


\section{INTRODUCTION}

Casein, being a mixture of $\alpha_{\mathrm{S}^{-}}, \alpha_{\mathrm{S} 2^{-}}, \beta$ and $\kappa$-casein fractions, represents an important and valuable source of ingredients due to its specific nutritional and functional properties [42, 43, 63, 73].

The solubility of main casein fractions in water is a function of the $\mathrm{pH}$, temperature, dielectric constant, ionic strength and ionic environment (calcium and phosphate content) $[7,11,16,19,55,56,58,59]$.

Since the introduction in the XIXth century of the alcohol test for grading milk, several articles have been published on milk stability in ethanol solutions as a function of both alcohol concentration and $\mathrm{Ca}$, $\mathrm{Mg}, \mathrm{Na}, \mathrm{K}$, phosphate and citrate ion content, as well as pH, rennet, microbial contamination and genetic variants of casein fractions $[8,14,28,31-36,40,45,54,55$, $57,65,68,70,76,77]$.

Alcohol can also be used in the preparation and the purification of individual milk protein fractions $[30,39,78,80]$.

The stability of sodium caseinate in alcohol solutions is an important property for cream liqueur preparations [3-6, 15, 41, 46-48, 50].

Important differences in the secondary structure of milk proteins have been observed in alcohol - water solutions $[9,17,18]$.

The aim of this work was to analyse from a physicochemical point of view the combined effects of alcohol concentration and $\mathrm{pH}$ on the solubility, the electrostatic surface potential and the electrostatic surface energy of sodium caseinate in water-ethanol mixtures.

\section{MATERIALS AND METHODS}

Industrially produced, spray-dried sodium caseinate (Armor Proteines, 35466 Saint Brice en Cogles, France) was reconstituted in deionised water at $50{ }^{\circ} \mathrm{C}$ using a laboratory mixer, cooled to $20^{\circ} \mathrm{C}$ in a water bath and left overnight at room temperature to achieve a complete rehydration. To prevent bacterial growth and limit plasmin activity, $0.1 \mathrm{~g} \cdot \mathrm{L}^{-1} \mathrm{NaN}_{3}$ and $0.1 \mathrm{~g} \cdot \mathrm{L}^{-1}$ soybean trypsin inhibitor were added [11]. The $\mathrm{pH}$ of the solutions was adjusted to values in the 2.5-8.0 range with $0.5 \mathrm{~mol} \cdot \mathrm{L}^{-1} \mathrm{HCl}$ or $0.5 \mathrm{~mol} \cdot \mathrm{L}^{-1} \mathrm{NaOH}$ and allowed to equilibrate for $1 \mathrm{~h}$ at room temperature. Ethanol was slowly added at $20^{\circ} \mathrm{C}$ with continuous mixing, to reach the final ethanol volume fraction of up to 0.75 . The solutions were then kept for $1 \mathrm{~h}$ at $20^{\circ} \mathrm{C}$ and continuously stirred in a water bath. The casein concentration in final solutions was $10 \mathrm{~g} \cdot \mathrm{L}^{-1}$. Soluble caseins were separated from aggregates by centrifugation at $2000 \times g$ for $30 \mathrm{~min}$. Casein content in solutions and supernatants was estimated from nitrogen determinations.

The total solids content of the caseinates was estimated after drying to a constant weight at $102^{\circ} \mathrm{C}$. Total nitrogen (TN), nonprotein $\mathrm{N}(\mathrm{NPN})$ and non-casein $\mathrm{N}(\mathrm{NCN})$ were measured using Kjeldahl techniques with 6.38 as a nitrogen to protein conversion coefficient $[37,38]$. Calcium $(\mathrm{Ca})$, sodium $(\mathrm{Na})$, magnesium $(\mathrm{Mg})$ and potassium $(\mathrm{K})$ concentrations were measured with a Varian SpectrAA 55B atomic absorption spectrometer. The $\mathrm{pH}$ of water and ethanol solutions was measured with a Radiometer pHM meter equipped with a combination electrode. Calibration was performed with buffers in aqueous solution. The relative permittivities of aqueous ethanol solutions were calculated according to Åkerlöf [1], Harvey and Prausnitz [27] and Smith et al. [64].

The ionic strength was calculated according to the relation:

$$
I=0.5 \Sigma \mathrm{m}_{\mathrm{i}} \mathrm{z}_{\mathrm{i}}^{2}
$$

where: $(\mathrm{m})$ denotes the molarity and $(\mathrm{z})$ the valence of the dissolved ions.

The activity coefficient $(\gamma)$ of the ions was calculated by the equation [74]:

$$
\gamma=\exp \left[-42 \times 10^{5}\left|z_{+} z_{-}\right| \sqrt{\frac{\mathrm{I}_{\mathrm{T}}}{(\varepsilon \mathrm{T})^{3}}}\right]
$$

where: $\left(\mathrm{z}_{+}\right)$and $\left(\mathrm{z}_{-}\right)$are the valences of the positive and negative ions present in the solution, $(\varepsilon)$ is the relative dielectric constant of the solvent and $(\mathrm{T})$ is the absolute temperature. 


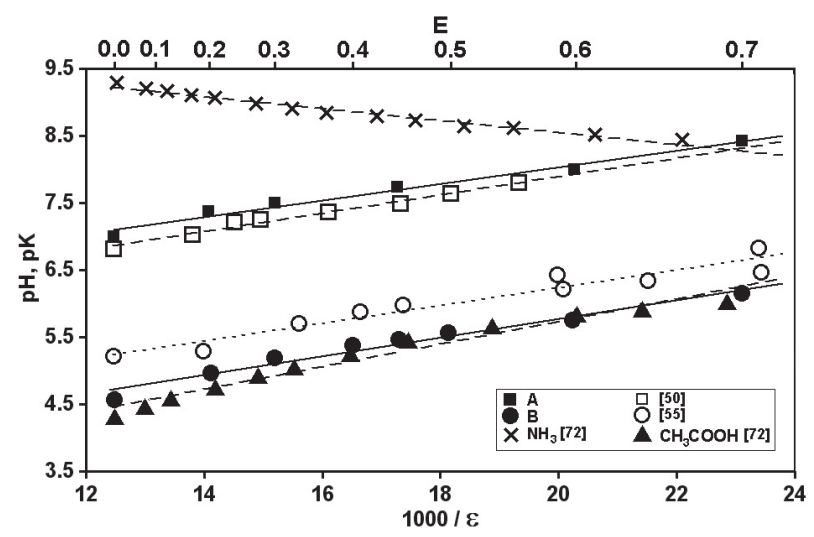

Figure 1. The $\mathrm{pH}$ shift of sodium caseinate in water/ ethanol solutions as a function of the reciprocal relative dielectric constant $(\varepsilon): \mathrm{E}=$ ethanol volume fraction. $(\mathbf{\square})-10 \mathrm{~g} \cdot \mathrm{L}^{-1}$ sample $(\mathrm{A})-$ initial $\mathrm{pH}$ 7.0; ( $\square)-30 \mathrm{~g} \cdot \mathrm{L}^{-1}$ sodium caseinate [50]; $(\bullet)-10 \mathrm{~g} \cdot \mathrm{L}^{-1}$ sample $(\mathrm{B})=$ sample A with initial $\mathrm{pH}$ adjusted to 4.6; (O) - minimum ethanol stability of sodium caseinate [55]; ( $\mathbf{\Delta})$ - apparent pK of acetic acid [72]; (X) - apparent pK of ammonium [72]. Solid, broken and dotted lines represent equation (1) with coefficients A and 1/B given in Table I.

The hypothetical concentration of the ionised acidic $\left(\mathrm{z}_{-}\right)$or basic $\left(\mathrm{z}_{+}\right)$amino acids in mol per mol of protein, as a function of $\mathrm{pH}$, was estimated by applying the relations [74]:

$$
\begin{aligned}
& \mathrm{z}_{-}=\frac{\mathrm{A}_{\mathrm{a}}}{1+10^{\left[\mathrm{pK}_{\mathrm{a}}-\mathrm{pH}+\log (\gamma)\right]}} \\
& \mathrm{z}_{+}=\frac{\mathrm{A}_{\mathrm{b}}}{1+10^{\left[\mathrm{pH}-\mathrm{pK}_{\mathrm{a}}-\log (\gamma)\right]}}
\end{aligned}
$$

where: $\left(A_{a}\right)$ and $\left(A_{b}\right)$ are, respectively, the concentrations, in mol per mol of protein, of a given acidic or basic amino acid and $\mathrm{pK}_{\mathrm{a}}$ is the intrinsic acid dissociation constant, i.e. the $\mathrm{pH}$ level at which the dissociation is exactly $50 \%$ for the ionic strength $\mathrm{I}=0 ;(\gamma)$ is the activity coefficient.

\section{RESULTS AND DISCUSSION}

\subsection{Composition}

The sodium caseinate used in this study contained over $930 \mathrm{~g} \cdot \mathrm{kg}^{-1}$ dry matter and over $960 \mathrm{~g} \cdot \mathrm{kg}^{-1}$ casein in total protein. It is consistent with the results of Muir and
Dalgleish [48] obtained for industrial sodium caseinates. The sodium content of about $14.6 \mathrm{~g} \cdot \mathrm{kg}^{-1}$ was in agreement with the results of Towler [69-71]. The potassium and the magnesium contents were $2.5 \mathrm{~g} \cdot \mathrm{kg}^{-1}$ and $0.3 \mathrm{~g} \cdot \mathrm{kg}^{-1}$, respectively. The calcium level $\left(1.5 \mathrm{~g} \cdot \mathrm{kg}^{-1}\right)$ was close to that found by Muir and Dalgleish [48] for sodium caseinates from various suppliers.

\section{2. pH shift}

For ethanol volume fractions up to 0.75 , the $\mathrm{pH}$ of sodium caseinate solutions rose linearly with the increase in the reciprocal relative dielectric constant $(\varepsilon)$ according to the relation (Fig. 1):

$$
\mathrm{pH}=\mathrm{A}+\mathrm{B} / \varepsilon+\mathrm{Err}
$$

where: $\mathrm{A}$ is the intercept or the $\mathrm{pH}$ level for the hypothetical $\varepsilon=\infty$, and the slope coefficient $\mathrm{B}$ indicates the hypothetical $\mathrm{pH}$ increase for unitary increase in $1 / \varepsilon$; Err is the standard error term following a normal distribution. More evocative is the reciprocal value of the coefficient $B$, which indicates the change in $1 / \varepsilon$ causing the $\mathrm{pH}$ or the apparent $\mathrm{pK}$ to change by 1 unit:

$\mathrm{A}+\mathrm{B} / \varepsilon=\mathrm{A}+\mathrm{B} / \varepsilon_{\mathrm{w}}+1$, so $1 / \varepsilon=1 / \varepsilon_{\mathrm{w}}+1 / \mathrm{B}$ 
Table I. Intercept (A), slope (B), standard error (Err) and correlation coefficient $\left(\mathrm{R}^{2}\right)$ from Equation (5) expressing the relation between the $\mathrm{pH}$ or the apparent $\mathrm{pK}$ and the reciprocal dielectric constant $(1 / \varepsilon)$ presented in Figure $1 . \mathrm{N}=$ number of experimental points.

\begin{tabular}{lccccccc}
\hline Sample & $\mathrm{A}$ & $\mathrm{B}$ & $\mathrm{Err}$ & $\mathrm{R}^{2}$ & $\mathrm{~N}$ & $\begin{array}{c}\mathrm{pH}_{1} \text { or } \\
\mathrm{pK}_{1}\end{array}$ & $\mathrm{E}_{1}$ \\
\hline Sample (A) & $5.75 \pm 0.27$ & $123 \pm 8.1$ & 0.079 & 0.934 & 6 & 8.19 & 0.63 \\
Sample (B) & $3.00 \pm 0.17$ & $139 \pm 9.8$ & 0.088 & 0.971 & 8 & 5.73 & 0.57 \\
Pierre [55] & $3.56 \pm 0.23$ & $132 \pm 12.3$ & 0.141 & 0.934 & 10 & 6.23 & 0.58 \\
$\mathrm{CH}_{3} \mathrm{COOH}$ [72] & $2.35 \pm 0.17$ & $209 \pm 6.9$ & 0.113 & 0.967 & 12 & 5.46 & 0.51 \\
O'Kennedy et al. [50] $^{\prime} 5.17 \pm 0.11$ & $137 \pm 6.9$ & 0.044 & 0.984 & 8 & 7.86 & 0.58 \\
$\mathrm{NH}_{3}$ [72] & $10.3 \pm 0.06$ & $-88.9 \pm 3.7$ & 0.039 & 0.976 & 15 & 11.46 & 0.71 \\
\hline
\end{tabular}

$\mathrm{pH}_{1}$ or $\mathrm{pK}_{1}$ shows the $\mathrm{pH}$ or $\mathrm{pK}$ level for the reciprocal relative dielectric constant $1 / \varepsilon=\left(1 / \varepsilon_{\mathrm{w}}+1 / \mathrm{B}\right)$, where $\varepsilon_{\mathrm{w}}=80.2$ at $20{ }^{\circ} \mathrm{C}$ is the relative dielectric constant of water.

$\mathrm{E}_{1}=$ ethanol volume fraction corresponding to $\mathrm{pH}_{1}$ or $\mathrm{pK}_{1}$.

where $\varepsilon_{\mathrm{w}}=80.2$ at $20^{\circ} \mathrm{C}$ is the relative dielectric constant of water.

The values of $\mathrm{A}$ and $\mathrm{B}$ are given in Table I.

The sodium caseinate samples examined in this study gave very similar tendencies in $1 / \mathrm{B}$ to those calculated from the results of Pierre [55] and O'Kennedy et al. [50]. The apparent $\mathrm{pK}$ change in the acetic acid [72] was also close to the values obtained for different samples of sodium caseinate. Contrary to carboxyl groups, the apparent $\mathrm{pK}$ of amino groups decreases with the increased in the reciprocal relative dielectric constant [72]. The $\mathrm{pK}$ reduction rate of the amino groups was about $20 \%$ lower than that of the carboxyl groups.

When the reciprocal dielectric constant $(1 / \varepsilon)$ increased from its initial level $(1 / 80.2=$ $1.25 \times 10^{-2}$ ) by $1 / \mathrm{B}$ from equation (1), the $\mathrm{pH}$ or the apparent $\mathrm{pK}$ of carboxyl groups increased by one unit to $\mathrm{pH}_{1}$ or $\mathrm{pK}_{1}$ (Tab. I). This happened when the ethanol volume fraction reached 0.5 to 0.7 for different samples and groups $\left(\mathrm{E}_{1}\right.$ in Tab. I).

The phenomenon of $\mathrm{pH}$ or $\mathrm{pK}$ changes is due to the evolution of the electrostatic energy when an ion is transferred from one solvent to another one, both characterised by the relative dielectric constants $\left(\varepsilon_{1}\right)$ and $\left(\varepsilon_{2}\right)$. According to Max Born's model of the electrostatic work (W in joules $\mathrm{J}$ ) required to transfer an ion of a radius ( $r$ ) and the charge $(\mathrm{z})$ is equal to [72]:

$$
\mathrm{W}=\mathrm{e}^{2} \mathrm{z}^{2}\left(1 / \varepsilon_{1}-1 / \varepsilon_{2}\right) /\left(8 \pi \mathrm{r} \varepsilon_{0}\right)
$$

where: $\mathrm{e}=$ elementary electronic charge $=$ $1.602 \times 10^{-19} \mathrm{C}, \pi=3.14, \quad \varepsilon_{0}=8.854 \times$ $10^{-12} \mathrm{~J}-1 \cdot \mathrm{C}^{2} \cdot \mathrm{m}^{-1}=$ dielectric permittivity of vacuum.

For casein monomers at $\mathrm{pH} 7$ with a radius of around $4.5 \mathrm{~nm}$ [66], the electrostatic work (W) is about $30 \mathrm{~kJ} \cdot \mathrm{mol}^{-1}$ for the passage from water to $60 \%$ ethanol, which is the average alcohol concentration for $\mathrm{pH}_{1}$, calculated for samples $\mathrm{A}$ and $\mathrm{B}$ and those of Pierre [55] and O' Kennedy et al. [50].

\subsection{Protein solubility}

The solubility profile (Fig. 2) below and above the isoelectric point follows the Linderstrøm-Lang equation (7), representing the ionisation process [32-34]:

$\log _{10}\left[\left(\mathrm{~S}-\mathrm{S}_{\min }\right) /\left(\mathrm{S}_{\max }-\mathrm{S}\right)\right]=\left(\mathrm{pH}_{50 \%}-\mathrm{pH}\right) / \mathrm{D}$

where: $\mathrm{pH}_{50 \%}$ is the $\mathrm{pH}$ inflexion point or the $\mathrm{pH}$ corresponding to $50 \%$ casein solubility; D is the slope of the straight line in $\mathrm{pH}$ versus $\log _{10}\left[\left(\mathrm{~S}-\mathrm{S}_{\min }\right) /\left(\mathrm{S}_{\max }-\mathrm{S}\right)\right]$ coordinates, $S_{\min }$ and $S_{\max }$ are, respectively, the minimal and maximal casein solubility 


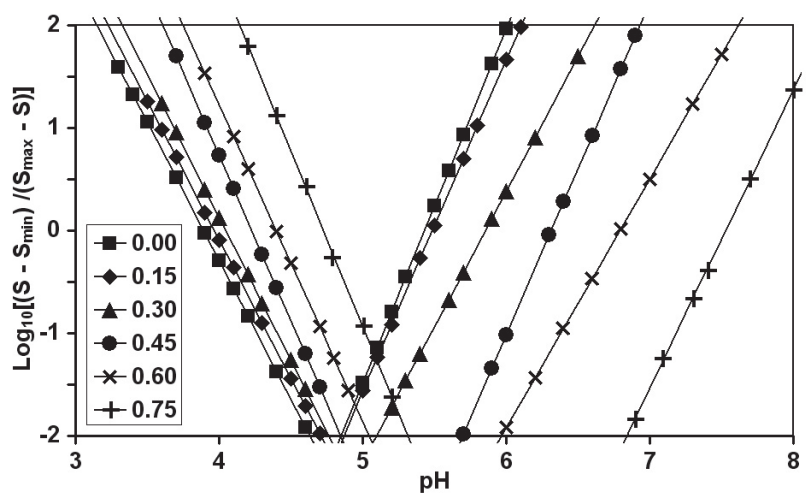

Figure 2. The effect of $\mathrm{pH}(3-8)$ and ethanol volume fraction $(0-0.75)$ on the solubility profile of $10 \mathrm{~g} \cdot \mathrm{L}^{-1}$ sodium caseinate solutions. Solid lines represent Equation (3) with coefficients $\mathrm{pH}_{\mathrm{i}}$ and $\mathrm{D}$ presented in Figure 3 and Table II.

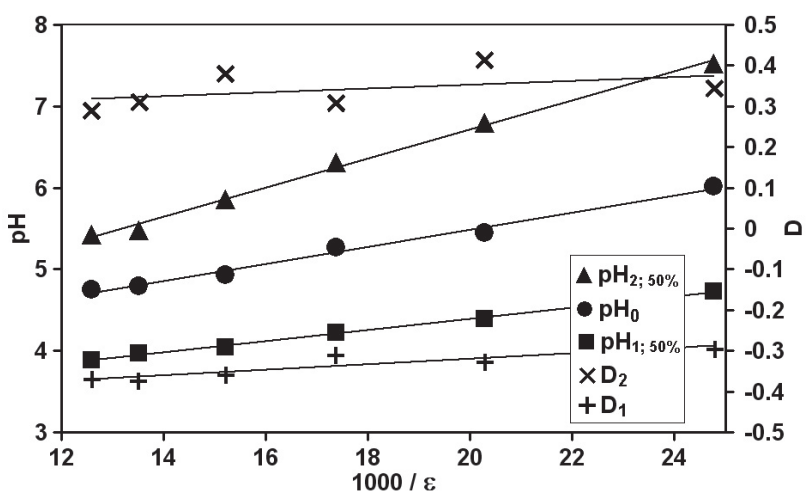

Figure 3. Evolution of $\mathrm{pH}$ corresponding to $50 \%$ casein solubility $\left(\mathrm{pH}_{1: 50 \%}\right.$ and $\left.\mathrm{pH}_{2: 50 \%}\right)$ and coefficient $\mathrm{D}$ from Equation (3) as a function of the reciprocal relative dielectric constant $(1 / \varepsilon)$ for the $\mathrm{pH}$ range below $\left(\mathrm{pH}_{1}\right.$ and $\left.\mathrm{D}_{1}\right)$ and over $\left(\mathrm{pH}_{2}\right.$ and $\left.\mathrm{D}_{2}\right)$ the minimal solubility point $\left(\mathrm{pH}_{0}\right)$. Solid lines represent Equation (1) with coefficients $\mathrm{A}$ and $\mathrm{B}$ given in Table II.

and $\mathrm{S}$ is the solubility at a given $\mathrm{pH}$ and ethanol concentration.

Equation (7) can also be presented in the form:

$$
\boldsymbol{S}=\frac{\mathrm{S}_{\min }+\mathrm{S}_{\max } \times 10^{\left(\mathrm{pH}_{50 \%}-\mathrm{pH}\right) / \mathrm{D}}}{1+10^{\left(\mathrm{pH}_{50 \%}-\mathrm{pH}\right) / \mathrm{D}}}
$$

For the $\mathrm{pH}$ range below the minimal solubility point $\left(\mathrm{pH}_{0}\right), \mathrm{pH}_{1 ; 50 \%}$ from equations (7 or 8 ) increased linearly between 3.7 and 4.6 with the rise in $1 / \varepsilon$ (Fig. 3, Tab. II). For $\mathrm{pH}$ values over the minimal solubility point, $\mathrm{pH}_{2,50 \%}$ rose much more (5.2 to 7.4$)$. The lowest level of casein solubility $\left(\mathrm{pH}_{0}\right)$ in water occured at $\mathrm{pH} 4.7$ and increased linearly with the rise in $1 / \varepsilon$ (Fig. 3). The low solubility zone broadened with the increase in ethanol concentration. A similar tendency for casein solubility in water and in up to $66 \%$ ethanol was observed by Zittle and Pepper [79] and by Pierre [55]. The variation in the coefficient D from equation (8) is 
Table II. Intercept (A), slope (B), standard error (Err) and correlation coefficient $\left(\mathrm{R}^{2}\right)$ from Equation (5) expressing the linear relations between the $\mathrm{pH}$ and coefficient (D) from Equation (7) and the reciprocal dielectric constant $(1 / \varepsilon)$ presented in Figure 3. Number of experimental points $\mathrm{N}=6$.

\begin{tabular}{lcccc}
\hline & A & B & Err & $\mathrm{R}^{2}$ \\
\hline $\mathrm{pH}_{1 ; 50 \%}$ & $3.03 \pm 0.03$ & $68 \pm 1.6$ & 0.017 & 0.998 \\
$\mathrm{pH}_{2 ; 50 \%}$ & $3.16 \pm 0.10$ & $178 \pm 5.6$ & 0.058 & 0.996 \\
$\mathrm{pH}_{0}$ & $3.39 \pm 0.10$ & $104 \pm 5.7$ & 0.060 & 0.988 \\
$\mathrm{D}_{1}$ & $0.45 \pm 0.03$ & $-6.7 \pm 1.5$ & 0.015 & 0.838 \\
$\mathrm{D}_{2}$ & $-0.26 \pm 0.08$ & $-4.8 \pm 4.6$ & 0.048 & 0.211 \\
\hline
\end{tabular}

relatively small in comparison with the experimental error (Fig. 3). It is positive for the $\mathrm{pH}$ range below the minimal solubility point. For the $\mathrm{pH}$ range over the minimal solubility point, it is negative and on average does not change with the rise in the ethanol concentration. In absolute terms, there is no statistically significant difference between $\mathrm{D}_{1}$ and $\mathrm{D}_{2}$ and their average level is $0.339 \pm 0.039$.

Around $\mathrm{pH}_{50 \%}$ points for $\mathrm{pH}$ values below and above the minimal solubility point, the casein solubility decreased or increased very rapidly with $\mathrm{pH}$ change. Thus, any slight imperfections in the estimation of $\mathrm{pH}$ or in the solubility cause quite a significant scattering of the coefficient $\mathrm{D}$ between different individual casein solubility curves as a function of $\mathrm{pH}$ for a given ethanol concentration (Fig. 3). Nevertheless, for the whole set of data, the regression line between the experimental $\left(S_{\mathrm{EXP}}\right)$ and model $\left(\mathrm{S}_{\mathrm{MOD}}\right)$ values of casein solubility for $\mathrm{N}=150$ experimental points gives a standard error of around 3\%, which is quite satisfactory:

$\mathrm{S}_{\mathrm{MOD}}=0.1( \pm 0.35)+0.996( \pm 0.005) \mathrm{S}_{\mathrm{EXP}}$
$\mathrm{R}^{2}=0.996 ; \mathrm{Err}=2.8 ; \mathrm{N}=150$.

The casein solubility evolution (Fig. 4), calculated by equation (8) shows two solubility zones over $90 \%$, limited by the isolines joining the points of $\mathrm{pH} 3.5$ for water with $\mathrm{pH} 4.6$ for a 0.8 ethanol volume fraction and $\mathrm{pH} 5.7$ for water with $\mathrm{pH} 8.3$ for a 0.8 ethanol volume fraction. The lower solubility zone $(<10 \%)$ is limited by the isolines passing from $\mathrm{pH} 4.2$ for water to $\mathrm{pH}$ 5.1 at 0.8 ethanol volume fraction and from pH 5.1 at $0 \%$ to pH 7.6 for $80 \%$ ethanol solutions. Between these relatively flat lower or higher solubility zones, there are two very steep zones of decreasing and

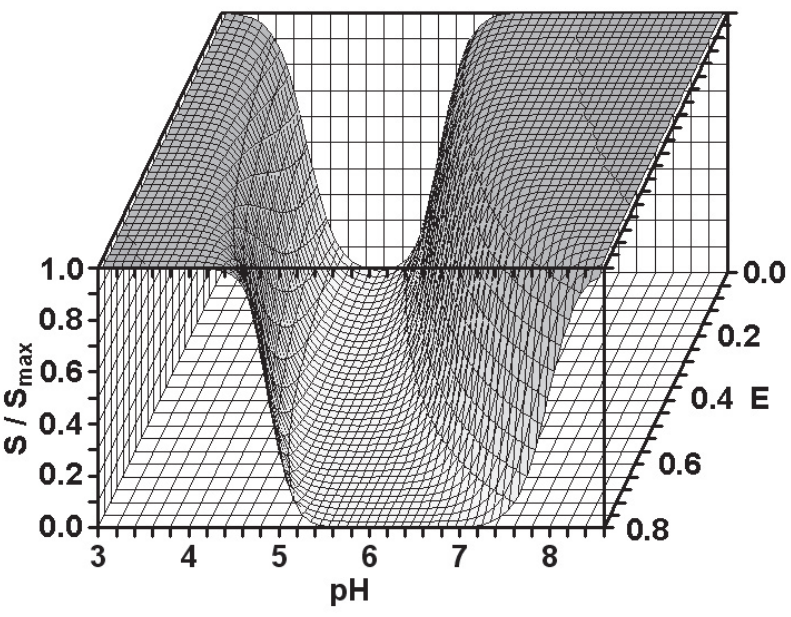

Figure 4. Relative casein solubility $\left(\mathrm{S} / \mathrm{S}_{\mathrm{max}}\right)$ as a function of $\mathrm{pH}$ and ethanol volume fraction $(\mathrm{E})$, calculated by Equation (8) with $\mathrm{S}_{\min }=0, \mathrm{~S}_{\max }=100$ and with average $\mathrm{pH}_{50 \%}$ and D coefficients calculated by the regression equations from Table II. 


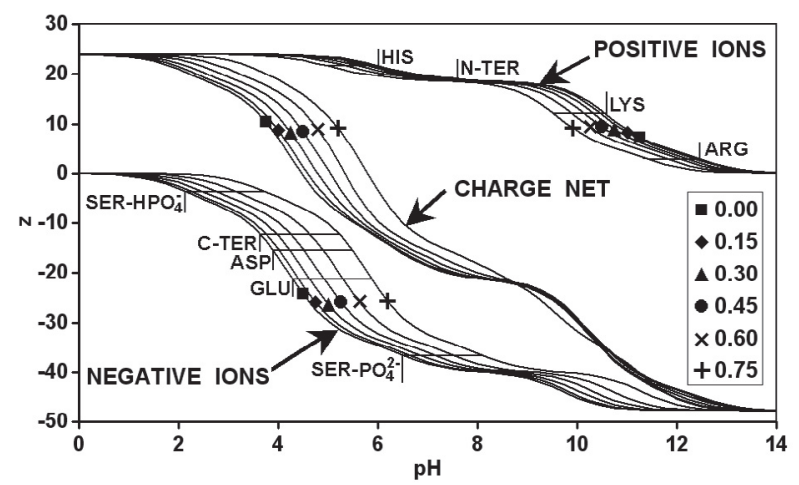

Figure 5. Evolution of the electrical charge (z) of total casein monomers, as a function of $\mathrm{pH}$ and ethanol volume fraction (0 to 0.75 ), calculated by Equations (3) and (4) with $\gamma=1$ and pK taken from Walstra and Jenness [75]. Horizontal lines with amino acid name abbreviations representing their apparent $\mathrm{pK}$ evolution as a function of the ethanol volume fraction $(0-0.75)$.

Table III. Intercept (A), slope (B), standard error (Err) and correlation coefficient $\left(\mathrm{R}^{2}\right)$ from Equation (5) representing the isolines of $10 \%$ and $90 \%$ of casein solubility (Fig. 4 ) and expressing the linear relations between the $\mathrm{pH}$ and the reciprocal dielectric constant $(1 / \varepsilon)$. Number of experimental points $\mathrm{N}=6$.

\begin{tabular}{cccc}
\hline A & B & Err & $\mathrm{R}^{2}$ \\
\hline $\mathrm{pH}_{1 ; 10 \%} 3.46 \pm 0.004$ & $62 \pm 0.2$ & 0.003 & 0.999 \\
$\mathrm{pH}_{2 ; 10 \%} 2.71 \pm 0.009$ & $166 \pm 0.5$ & 0.007 & 0.999 \\
$\mathrm{pH}_{1 ; 90 \%} 2.59 \pm 0.00674 .6 \pm 0.3$ & 0.005 & 0.999 \\
$\mathrm{pH}_{2 ; 90 \%} 3.41 \pm 0.003$ & $182 \pm 0.2$ & 0.002 & 0.999 \\
\hline
\end{tabular}

increasing solubility with rising $\mathrm{pH}$. In $\mathrm{pH}$ against $(1 / \varepsilon)$ coordinates (Fig. 4, Tab. III), the $10 \%$ and $90 \%$ isolines of casein solubility can be represented by equation (5).

\subsection{Ionisation}

Protein solubility is in general a function of the intermolecular repulsion and attraction forces that depend mainly on the electrical charge, ionic strength and dielectric constant.

On average, the native casein contains $190 \mathrm{mmol} \cdot \mathrm{kg}^{-1}$ of histidine, 560 of lysine, 220 of arginine, 220 of aspartic acid, 740 of glutamic acid and 260 of phosphate groups [75]. In total, casein contains $1.35 \mathrm{~mol} \cdot \mathrm{kg}^{-1}$ of anionic groups against $0.78 \mathrm{~mol} \cdot \mathrm{kg}^{-1}$ of cationic groups.

The content of $\alpha_{\mathrm{S}^{-}}, \alpha_{\mathrm{S}^{-}}, \beta$ - and $\kappa$ caseins in total casein is on average equal, respectively, to $40.2,10.5,37.4$ and $11.9 \%$ $[66,67]$. On the basis of these proportions and on the known amino acid composition of the main casein fractions, we calculated the average content of the ionic groups in total casein.

The ionic casein groups, dissociated within the 4 to $9 \mathrm{pH}$ range are $\gamma$ - and $\delta$ carboxyl groups of the aspartic and glutamic acids and the amino group of histidine with pKs of $4.1,4.6$ and 6.4 , respectively $[55,74,75]$. Typically for strong acids, the $\mathrm{pK}$ of the first $\mathrm{H}^{+}$of the serine phosphate (pK 2.12) is only slightly dependent on the dielectric constant changes with ethanol concentration up $80 \%$ [72]. For the second $\mathrm{H}^{+}$of phosphate esters, the $\mathrm{pK} 7.21$ would increase as for other weak acids. The pK of amino groups decreases by 1 unit with the average increase in the ethanol volume fraction from 0 to 0.73 [72]. So, in $73 \%$ (v/v) ethanol the $\mathrm{pK}$ of the imidazole group of histidine would be 5.4 , that of the $\varepsilon$-amino group of lysine would decrease from 10.6 to 9.6 and of the guanidine group of arginine from 12.5 to 


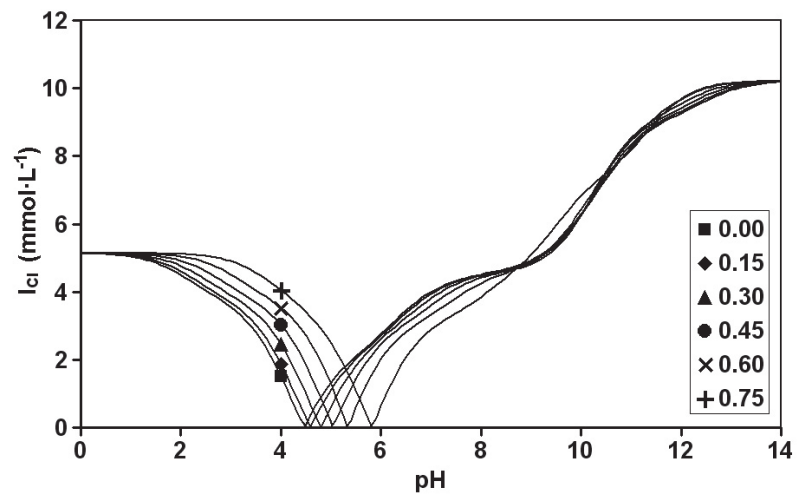

Figure 6. Evolution of the counter ions' ionic strength $\left(\mathrm{I}_{\mathrm{CI}}\right)$ in $\mathrm{mol} \cdot \mathrm{L}^{-1}$, as a function of $\mathrm{pH}$ and ethanol volume fraction ( 0 to 0.75 ), calculated by Equation (1), with $\mathrm{m}=0.428 \mathrm{mmol} \cdot \mathrm{L}^{-1}$ and the net charge $(\mathrm{z})$ taken from Figure 5.

11.5. In water solution at $\mathrm{pH} 7$ only histidine is at about $80 \%$ in its neutral form and at $20 \%$ in its protonated form. Lysine and arginine remain almost totally in their protonated forms up to $\mathrm{pH}$ 9. In $60 \%$ ethanol solutions the carboxyl groups would be 10 times less dissociated than in water. On the other hand, in $73 \%$ ethanol the amino groups would be 10 times less protonated, but among them only histidine can play a minor role in electrical charge modification of casein molecules.

For a given $\mathrm{pH}$ of casein water solution, when alcohol was added, the $\mathrm{pH}$ increased spontaneously, because of the apparent $\mathrm{pK}$ changed as an effect of the dielectric constant variation, but the electrical charge of a protein molecule or protein aggregate did not change (Fig. 5). On the other hand, for the same $\mathrm{pH}$ level for water and ethanol solutions, the charge differences can be very significant. For $\mathrm{pH}$ values between 0 and 3 , the amino casein groups are $>99.98 \%$ protonated. At $\mathrm{pH} 14$ about $99.3 \%$ of amino groups are in their neutral form. At $\mathrm{pH}<1$, over $98.8 \%$ of the acidic casein groups are not dissociated. At $\mathrm{pH}>11$ in water solution and at $\mathrm{pH}>12.5$ in $75 \%$ ethanol solutions, over $99.5 \%$ of acidic groups are dissociated. Only at $\mathrm{pH}<1$ and over 13.5 is there practically only one sort of charge: positive at low $\mathrm{pH}$ and negative at high $\mathrm{pH}$ levels. At $\mathrm{pH}<1$, the average electrical charge $(z)$ of casein aggregates is +24 and at $\mathrm{pH} 14$ it is -48 . Zero charge, i.e. equal numbers of positive and negative charges in a casein molecule or aggregate, is at $\mathrm{pH}$ 4.57 for water solutions and increases to $\mathrm{pH}$ 5.79 for 0.75 ethanol volume fractions. Swaisgood [66] found isoionic $\mathrm{pH}$ values for water solutions of different casein fractions of between 4.94 and 5.90. For native phosphocaseinate dissolved in water, $50 \%$ protein solubility was observed at $\mathrm{pH} 5.2$ [21]. At $\mathrm{pH} 7.0$ the average net charge of total casein would be -18.7 in water solution and -13.6 in $75 \%$ ethanol. Because of the opposite effect of alcohol on the $\mathrm{pK}$ of amino and acidic groups, for $\mathrm{pH}>9$ the net charge of casein molecules and aggregates would almost be independent of the ethanol concentration.

\subsubsection{Ionic strength}

The solution containing $10 \mathrm{~g} \cdot \mathrm{L}^{-1}$ of sodium caseinate contains $7.09 \mathrm{mmol} \cdot \mathrm{L}^{-1}$ $\mathrm{Na}^{+}, 0.71 \mathrm{~K}^{+}, 0.42 \mathrm{Ca}^{2+}$ and $0.14 \mathrm{Mg}^{2+}$. The $\mathrm{pH}$ of this solution in water is 7.0. The minerals present in the solution represent an ionic strength of $5 \mathrm{mmol} \cdot \mathrm{L}^{-1}$. The contribution of the casein to the ionic strength is as significant as that of the minerals already present. As the solution must be electrically neutral, the counter ions $\left(\mathrm{Cl}^{-}\right.$or $\left.\mathrm{Na}^{+}\right)$have to be added to neutralise the protonated amino groups and the dissociated phosphoryl, carboxyl and thyrosyl groups. The ionic 


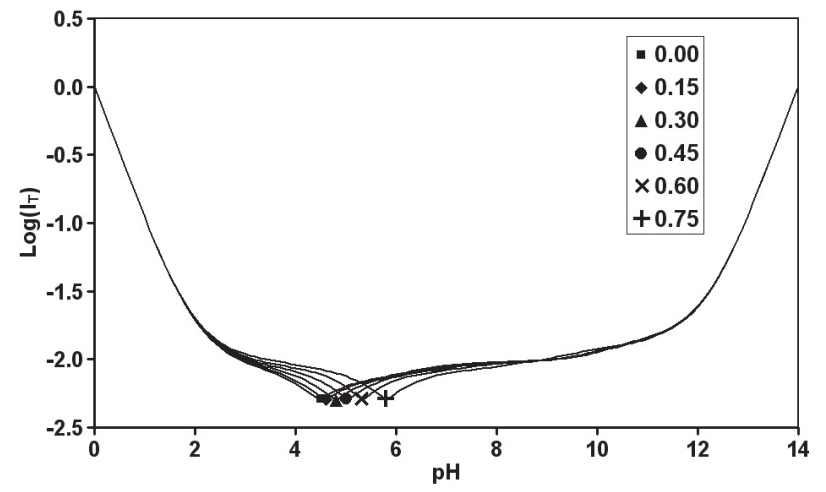

Figure 7. Evolution of the logarithm of the total ionic strength $\left(\mathrm{I}_{\mathrm{T}}\right.$ in $\left.\mathrm{mol} \cdot \mathrm{L}^{-1}\right)$, as a function of $\mathrm{pH}$ and ethanol volume fraction (0 to 0.75$)$, calculated using Equation (1).

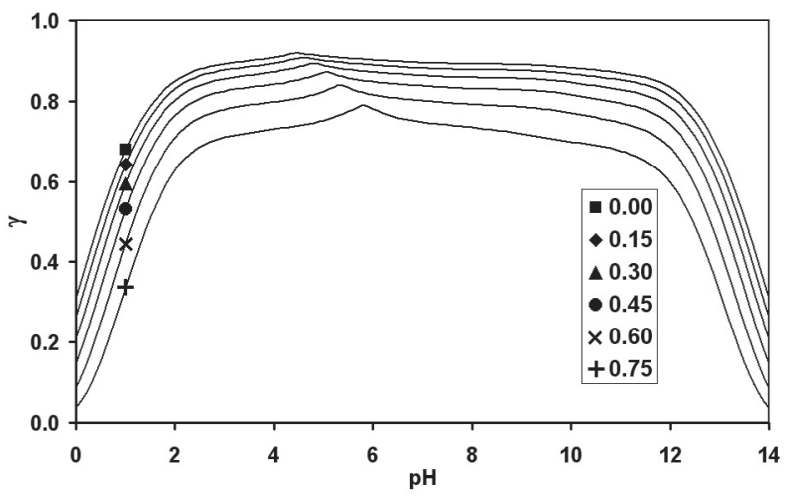

Figure 8. Evolution of the activity coefficient $(\gamma)$, as a function of $\mathrm{pH}$ and ethanol volume fraction (0 to 0.75 ), calculated by Equation (2) for $\mathrm{T}=293 \mathrm{~K}$.

strength, which represents the counter ions, varied between 0 at the isoelectric point and $5.1 \mathrm{mmol} \cdot \mathrm{L}^{-1}$ at $\mathrm{pH} 0$ and $10.2 \mathrm{mmol} \cdot \mathrm{L}^{-1}$ at $\mathrm{pH} 14$ (Fig. 6). The greatest contribution to the total ionic strength $\left(\mathrm{I}_{\mathrm{T}}\right.$ in Fig. 7) was the ions that were added to the solution to reach very low or very high $\mathrm{pH}$ level.

\subsubsection{Activity coefficient and electrical charge}

The activity coefficient $(\gamma)$, calculated by Equation (2), varied between 0.04 and 0.92 (Fig. 8). It is at its highest at the isoelectric point and decreases sharply in very low and very high $\mathrm{pH}$ regions. The presence of ethanol significantly reduces the activity coefficient.

When taking into account the activity coefficient $(\gamma)$ from Figure 8 in Equations (3) and (4), instead of $\gamma=1$, the level of the ionised acidic and basic amino acids became different from that presented in Figure 5. This difference, $\Delta \mathrm{z}=\mathrm{z}_{\gamma=1}-\mathrm{z}_{\gamma}$ (Fig. 9), increased with the rise in the ethanol volume fraction. With the increasing ionic strength and decreasing dielectric constant, the activity coefficient decreased, so less energy is needed to remove a proton from a charged molecule, as the proton senses a smaller electrostatic potential [74]. The observed differences 


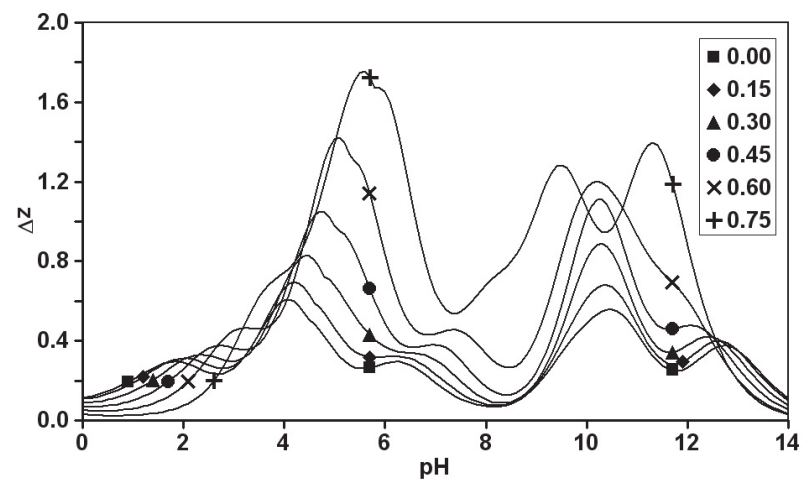

Figure 9. Evolution of the difference $\left(\Delta \mathrm{z}=\mathrm{z}_{\gamma=1}-\mathrm{z}_{\gamma}\right)$ between the net electrical charge $(\mathrm{z})$ of total casein monomers, calculated by Equations (3) and (4) for the activity coefficient $\gamma=1$ and for the values of $\gamma$ taken from Figure 8, as a function of $\mathrm{pH}$ and ethanol volume fraction (0 to 0.75$)$.

were greater around those $\mathrm{pH}$ levels close to the $\mathrm{pK}$ of the principal ionic amino acids, namely, glutamic and aspartic acids $(\mathrm{pK}=4.3$ and 3.9$)$ and lysine and arginine $(\mathrm{pK}=10.6$ and 12.5). Because of the opposing effects of the dielectric constant and the ionic strength on the apparent $\mathrm{pK}$ of basic amino acids, quite wide differences in $\Delta \mathrm{z}$ were observed between 0.6 and 0.75 ethanol volume fractions. Close to the isoelectric point $(4<\mathrm{pH}<6)$, the observed differences in $\Delta \mathrm{z}$ were larger than at the potential casein molecule charge within this $\mathrm{pH}$ range. However, as values grew further away from the isoelectric point these differences became relatively small, when the overall variation in $\mathrm{z}$ between +24 at $\mathrm{pH} 0$ and -48 at $\mathrm{pH} 14$ was taken into account.

\subsection{Electrostatic surface and zeta potentials}

Casein molecules can be considered as spheres of an average radius $\mathrm{r}=4.5 \mathrm{~nm}$ [66]. Their average electrostatic surface potential $\left(\psi_{0}\right)$ can be estimated by the relation:

$$
\psi_{0}=\mathrm{ze} /\left(4 \pi \varepsilon_{0} \varepsilon \mathrm{r}\right) \text {. }
$$

The $\psi_{0}=0$ at the isoelectric point $\left(\mathrm{pH}_{0}\right)$, which increases from about 4.5 for water solutions to 5.8 for 0.75 ethanol volume fractions (Fig. 10). For the $\mathrm{pH}<\mathrm{pH}_{0}$ range, the $\psi_{0}$ is positive and for $\mathrm{pH}>\mathrm{pH}_{0}$ it is negative. For casein dissolved in water or in $75 \%$ ethanol, the electrostatic surface potential at $\mathrm{pH} 0$ is $+95 \mathrm{mV}$ and $+191 \mathrm{mV}$, respectively. At pH 14 the $\psi_{0}$ is, respectively, -189 and $-376 \mathrm{mV}$.

The surface potential $\left(\psi_{0}\right)$ did not coincide strictly with the isoline $\mathrm{pH}_{0}$ from Figure 3 . The surface potential, corresponding to the isoline $\mathrm{pH}_{0}$, increased from $12 \mathrm{mV}$ for water solutions to $30 \mathrm{mV}$ for a 0.75 ethanol volume fraction (Fig. 11, Tab. IV). The absolute values of the electrostatic surface potentials $\psi_{1 ; 10 \%}, \psi_{2 ; 10 \%}, \psi_{1 ; 90 \%}$, and $\psi_{2 ; 10 \%}$, corresponding to $10 \%$ and $90 \%$ casein solubilities equal for the $\mathrm{pH}$ range below $\left(_{1}\right)$ and over $(2)$ the minimal $\mathrm{pH}$ solubilities, were inversely proportional to the relative dielectric constant (Fig. 11). Within the standard error limits of $( \pm 5 \mathrm{mV})$, the electrostatic surface potential levels were similar for the corresponding isolines on both sides of the minimal casein solubility or minimal surface potential. The surface potential difference between $90 \%$ and $10 \%$ casein solubility was on average $37 \pm$ $5.2 \mathrm{mV}$, independently of the dielectric constant of the solvent. This means that on both sides of the isoelectric point, an increase in the surface potential of about $40 \mathrm{mV}$ augments the casein solubility from $10 \%$ to $90 \%$. 


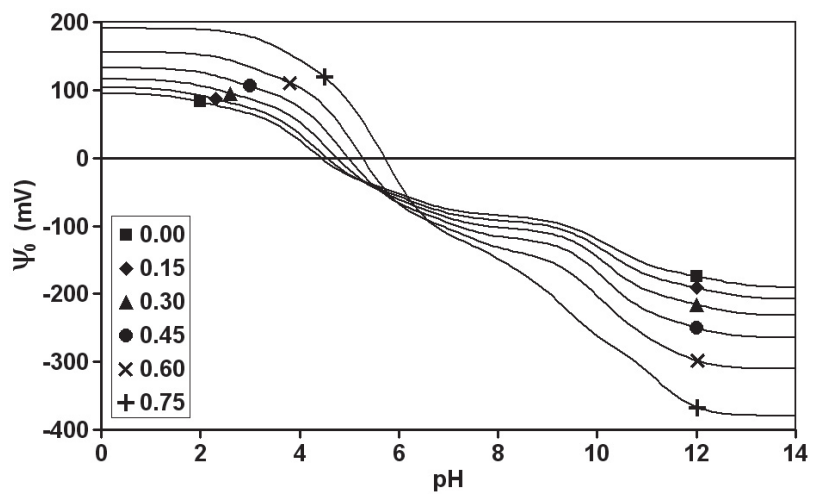

Figure 10. Evolution of the electrostatic surface potential $(\psi 6)$ of sodium caseinate monomers, as a function of $\mathrm{pH}$ and ethanol volume fraction $(\mathrm{E})$, calculated by Equation (9) with the charge (z) calculated by Equations (3) and (4) and the activity coefficient $(\gamma)$ by Equation (2).

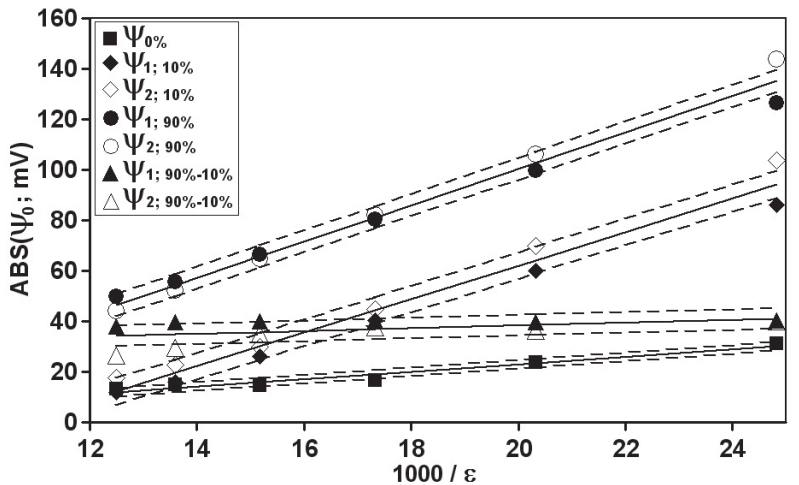

Figure 11. Absolute value of the electrostatic surface potential $\left(\psi_{0}\right)$ of casein monomers as a function of the reciprocal relative dielectric constant $(1 / \varepsilon)$ for the line $\mathrm{pH}_{0}$, from Figure $3(46 \%)$ and for the isolines $\mathrm{pH}_{1: 10 \%}, \mathrm{pH}_{2: 10 \%}, \mathrm{pH}_{1: 90 \%}$ and $\mathrm{pH}_{2: 90 \%}$ from Figure 4, corresponding to casein solubilities of $10 \%$ and $90 \%$ for the $\mathrm{pH}$ range below $\left(_{1}\right)$ and over $\left(_{2}\right)$ the minimal surface potential $\left(\psi_{6}\right)$. Solid lines represent Equation (5) with coefficients A and B given in Table IV and broken lines show standard deviation limits.

The electrostatic surface potential of protein molecules in solutions is partly screened by the counter ions present in the double layer. The potential at the double layer, being approximately equal to zeta potential $(\zeta)$, can be estimated by the relation [29]:

$$
\zeta=\psi_{0} \frac{\mathrm{r}}{\mathrm{r}+\lambda_{\mathrm{D}}} \exp (-1)
$$

where: $\lambda_{D}$ is the Debye length or the nominal thickness of the electric double layer, being a function of the relative dielectric constant of the solvent $(\varepsilon)$, the absolute temperature (T) and the total ionic strength $\left(\mathrm{I}_{\mathrm{T}}\right)$, according to the equation [74]:

$$
\lambda_{\mathrm{D}}=\sqrt{\frac{\varepsilon_{0} \varepsilon \mathrm{k}_{\mathrm{B}}^{\mathrm{T}}}{2 \mathrm{I}_{\mathrm{T}} \mathrm{N}_{\mathrm{A}} \mathrm{e}^{2}}}
$$

where: $\mathrm{k}_{\mathrm{B}}=1.381 \times 10^{-23} \mathrm{~J} \cdot \mathrm{K}^{-1}$ is the Boltzmann constant and $\mathrm{N}_{\mathrm{A}}=6.022 \times 10^{23}$ is the Avogadro number. 


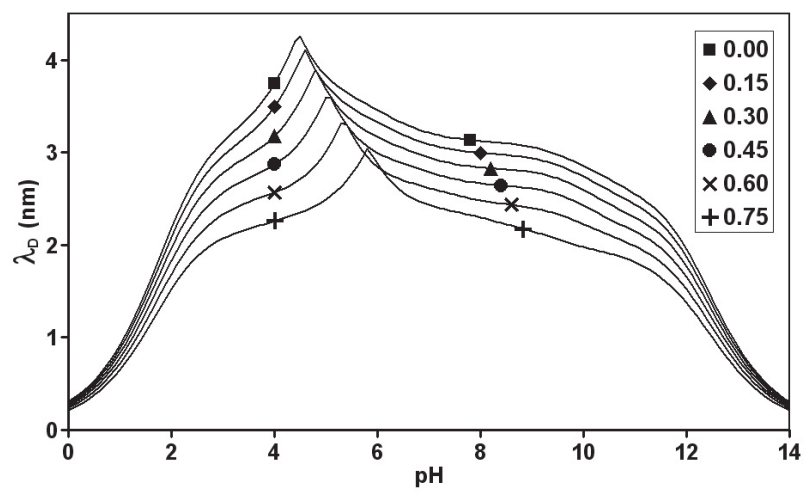

Figure 12. Evolution of the Debye length $\left(\lambda_{\mathrm{D}}\right)$, as a function of $\mathrm{pH}$ and of ethanol volume fraction (0 to 0.75 ), calculated by Equation (11) for $\mathrm{T}=293 \mathrm{~K}$.

Table IV. Intercept (A), slope (B), standard error (Err) and correlation coefficient $\left(\mathrm{R}^{2}\right)$ from Equation (5) expressing the relations between the absolute values of the electrostatic surface potential $\left(\psi_{0}\right.$ in $\left.\mathrm{mV}\right)$ and the reciprocal dielectric constant $(1 / \varepsilon)$ for the lines $\mathrm{pH}_{0}, \mathrm{pH}_{1: 50 \%}$ and $\mathrm{pH}_{2 ; 50 \%}$ from Figure 3, and the isolines $\mathrm{pH}_{1: 10 \%}, \mathrm{pH}_{2: 10 \%}, \mathrm{pH}_{1: 90 \%}$ and $\mathrm{pH}_{2: 90 \%}$ from Figure 11, corresponding to a casein solubility equal to $10 \%$ and $90 \%$ for the $\mathrm{pH}$ range below $\left(_{1}\right)$ and over $(2)$ the minimal solubility point $\left(\mathrm{pH}_{0}\right)$. $\mathrm{N}=$ number of experimental points.

\begin{tabular}{lrrccc}
\hline & $\mathrm{A}$ & $\mathrm{B}$ & Err & $\mathrm{R}^{2}$ & $\mathrm{~N}$ \\
\hline$\Psi_{0}$ & $-6.4 \pm 2.9$ & $1475 \pm 164$ & 1.7 & 0.953 & 6 \\
$\Psi_{1,2 ; 50 \%}$ & $-54 \pm 7.6$ & $7034 \pm 429$ & 6.3 & 0.964 & 12 \\
$\Psi_{1,2 ; 10 \%}$ & $-71 \pm 6.5$ & $6645 \pm 364$ & 5.3 & 0.710 & 12 \\
$\Psi_{1,2 ; 90 \%}$ & $-43 \pm 5.3$ & $7192 \pm 300$ & 4.4 & 0.983 & 12 \\
$\Psi_{1,2 ; 90 \%-10 \%}$ & $29 \pm 4.9$ & $547 \pm 278$ & 4.1 & 0.279 & 12 \\
\hline
\end{tabular}

The Debye length is the distance from the surface of the protein molecule, over which the electrostatic surface potential drops to $\exp (-1)=0.368$ of its initial level $\psi_{0}$. For the experimental conditions applied in this work, the nominal thickness of the electric double layer varied between 0.2 and $0.3 \mathrm{~nm}$ at very low or very high $\mathrm{pH}$ levels and 3.0 and $4.3 \mathrm{~nm}$ near the isoelectric points (Fig. 12). This means that $\lambda_{\mathrm{D}}$ varied between $5 \%$ and $95 \%$ of the average radius of casein monomers. For the same $\mathrm{pH}$ level, $\lambda_{\mathrm{D}}$ decreased progressively with the rise in the ethanol volume fraction. For casein micelles in milk, the Debye length is $\sim 1 \mathrm{~nm}[40,75]$.

The casein monomer zeta potential varied between +33 and $+67 \mathrm{mV}$ at $\mathrm{pH} 0$ and -65 and $-132 \mathrm{mV}$ at $\mathrm{pH} 14$ (Fig. 13). As with the electrostatic surface potential, the absolute value of the zeta potential decreased with drops in the ethanol volume fraction. Within the 4.5 to $6.6 \mathrm{pH}$ range, the effect of the ethanol volume fraction is opposite to that $4.5>\mathrm{pH}>6.6$. For milk $\mathrm{pH}$, the zeta potential decreased from $-16 \mathrm{mV}$ for water solution to $-26 \mathrm{mV}$ for $75 \%$ ethanol solution. The zeta potential of casein micelles in milk and in different buffers varied between -30 and $-10 \mathrm{mV}$ $[2,10,12,20,23,25,26,49,52,53]$. In absolute values, the zeta potential is lower for smaller micelles [51] and also decreases with the addition of calcium, magnesium, copper and iron ions [53], and when the $\mathrm{pH}$ is lowered $[2,13]$. When the ionic strength is high, the zeta potential may be much 


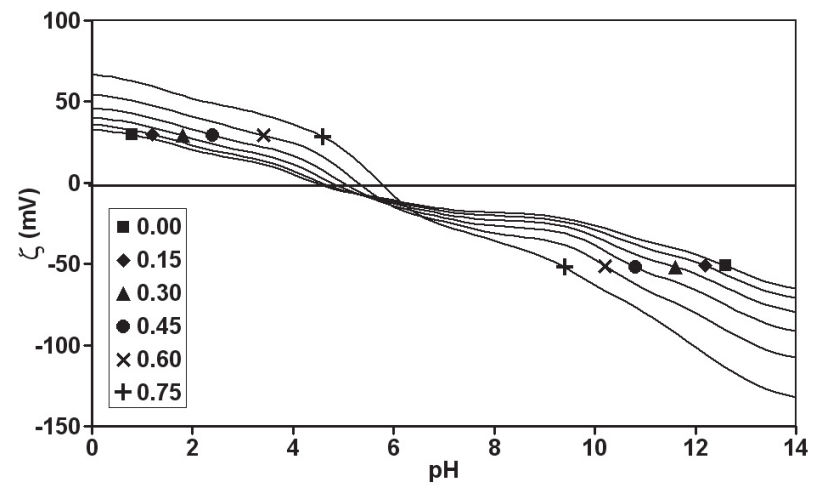

Figure 13. Evolution of the zeta potential $(\zeta)$ of casein monomers, as a function of $\mathrm{pH}$ and ethanol volume fraction ( 0 to 0.75 ), calculated by Equation (10) for $\mathrm{T}=293 \mathrm{~K}$.

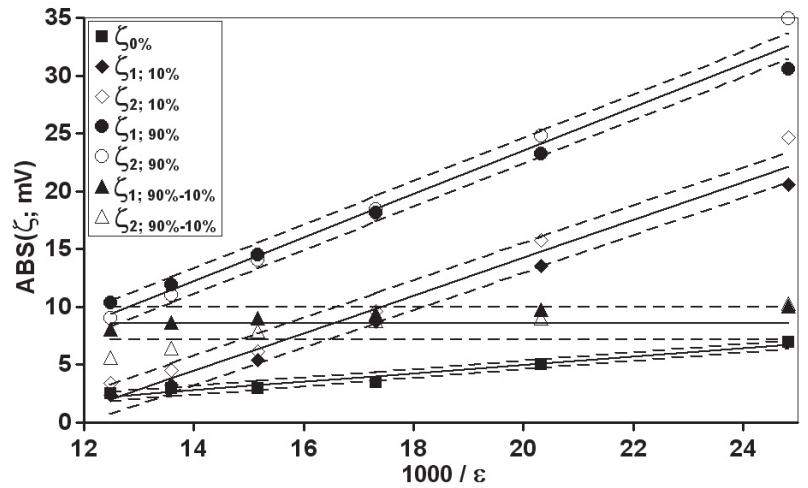

Figure 14. Absolute value of the zeta potential $(\zeta)$ of casein monomers as a function of the reciprocal relative dielectric constant $(1 / \varepsilon)$ for the line $\mathrm{pH}_{0}\left(\zeta_{0 \%}\right)$, from Figure 3 and the isolines $\mathrm{pH}_{1 \cdot 10 \%}$, $\mathrm{pH}_{2 ; 10 \%}, \mathrm{pH}_{1 ; 90 \%}$ and $\mathrm{pH}_{2 ; 90 \%}$ from Figure 4, corresponding to casein solubilities of $10 \%$ and $90 \%$ for the $\mathrm{pH}$ range below $(1)$ and over $(2)$ the minimal zeta potential $(\zeta)$. Solid lines represent Equation (5) with coefficients $\mathrm{A}$ and $\mathrm{B}$ given in Table $\mathrm{V}$ and broken lines show standard deviation limits.

smaller than the electrostatic surface potential $[10,52,53]$.

The zeta potential, corresponding to the isoline $\mathrm{pH}_{0}$ from Figure 3, increased from $+2.5 \mathrm{mV}$ for water solutions to $+7.0 \mathrm{mV}$ for ethanol volume fractions equal to 0.75 (Fig. 14, Tab. V). The absolute values of the zeta potentials $\zeta_{1 ; 10 \%}, \zeta_{2 ; 10 \%}, \zeta_{1 ; 90 \%}$, and $\zeta_{2 ; 10 \%}$, corresponding to casein solubilities of $10 \%$ and $90 \%$ for the $\mathrm{pH}$ range below $\left(_{1}\right)$ and over $(2)$ the minimal $\mathrm{pH}$ solubility, are inversely proportional to the relative dielectric constant. Within the limits of stand- ard error $( \pm 1.5 \mathrm{mV})$, the zeta potential levels are similar for the corresponding isolines on both sides of the minimal casein solubility or minimal surface potential. The zeta potential difference between $90 \%$ and $10 \%$ casein solubility is on average $8.6 \pm$ $1.4 \mathrm{mV}$, independently of the dielectric constant of the solvent. This means that on both sides of the isoelectric point, an increase in the zeta potential of about $9 \mathrm{mV}$ raises the casein solubility from $10 \%$ to $90 \%$.

Protein molecules in solution are also subjected to van der Waals attractive interactions, 
Table V. Intercept (A), slope (B), standard error (Err) and correlation coefficient $\left(\mathrm{R}^{2}\right)$ from Equation (5) expressing the relations between the absolute values of the zeta potential ( $\zeta$ in $\mathrm{mV}$ ) and the reciprocal dielectric constant $(1 / \varepsilon)$ for the lines $\mathrm{pH}_{0}, \mathrm{pH}_{1: 50 \%}$ and $\mathrm{pH}_{2 \cdot 50 \%}$ from Figure 3, and the isolines $\mathrm{pH}_{1: 10 \%}, \mathrm{pH}_{2: 10 \%}, \mathrm{pH}_{1: 90 \%}$ and $\mathrm{pH}_{2 ; 90 \%}$ from Figure 14, corresponding to a casein solubility equal to $10 \%$ and $90 \%$ for the $\mathrm{pH}$ range below $\left(_{1}\right)$ and over $\left(_{2}\right)$ the minimal solubility point $\left(\mathrm{pH}_{0}\right) \cdot \mathrm{N}=$ number of experimental points.

\begin{tabular}{lrcccc}
\hline & A & B & Err & $\mathrm{R}^{2}$ & $\mathrm{~N}$ \\
\hline$\zeta_{0}$ & $-2.3 \pm 0.7$ & $362 \pm 37$ & 0.4 & 0.960 & 6 \\
$\zeta_{1,2 ; 50 \%}$ & $-16 \pm 1.9$ & $1798 \pm 105$ & 1.5 & 0.967 & 12 \\
$\zeta_{1,2 ; 10 \%}$ & $-18 \pm 1.6$ & $1627 \pm 88$ & 1.3 & 0.972 & 12 \\
$\zeta_{1,2 ; 90 \%}$ & $-14 \pm 1.4$ & $1878 \pm 76$ & 1.1 & 0.984 & 12 \\
$\zeta_{1,2 ; 90 \%-10 \%}$ & $4 \pm 1.1$ & $251 \pm 62$ & 0.9 & 0.618 & 12 \\
\hline
\end{tabular}

which can partly or totally counterbalance the electrostatic repulsion. The Hamaker constant $\left(\mathrm{A}_{\mathrm{H}}\right)$ has to be known to determine the van der Waals interaction energy. However, the Hamaker constant has been determined for only very few proteins [24, 60]. Probably none of the casein family has been studied so far. For the same protein, depending on the method and the theoretical approach used, the Hamaker constant can vary between 2 and $10 \mathrm{k}_{\mathrm{B}} \mathrm{T}$ [24]. For casein micelles Kruif and Tuinier [40] applied $\mathrm{A}_{\mathrm{H}}=1 \mathrm{k}_{\mathrm{B}} \mathrm{T}$, assuming that the protein density of the casein micelles is 6 times lower than in globular proteins. Without having more precise evaluation of the Hamaker constant for caseins, it seems premature to estimate correctly the van der Waals attractive energy.

In this work we have presented the electrical charge $(\mathrm{z})$, the electrostatic surface potential $\left(\psi_{0}\right)$ and the zeta potential of hypothetical molecules with a weight average amino acid composition of four basic casein fractions $\alpha_{\mathrm{S1}^{-}}, \alpha_{\mathrm{S}_{2}-}, \beta$ - and $\kappa-$. The weight average molecular weight of this virtual, total casein would be $23.38 \mathrm{~kg} \cdot \mathrm{mol}^{-1}$. This approach seems to work for comparing the solubility of total casein with the electrostatic surface potential or the zeta potential of such a hypothetical total casein molecule.

In reality, the four basic casein fractions in solution coexist and interact independently. Their electrostatic surface potential $\left(\psi_{0}\right)$ as a function of $\mathrm{pH}$ is presented in Figure 15 . At $\mathrm{pH} 3$ in water solutions, it is $\alpha_{\mathrm{S}^{-}}$ casein that is the most positively charged
(+92 mV). At pH 6 to 9 it is $\alpha_{\mathrm{S}_{1}}$-casein that is most negatively charged $(-122 \mathrm{mV}$ at $\mathrm{pH}$ 9). So-called total casein ( $\mathrm{t}$ in Fig. 15) evolves somewhere in the middle. In $60 \%$ (v/v) ethanol solutions, the amplitude of the electrostatic surface potential increases to $+192 \mathrm{mV}$ at $\mathrm{pH} 3$ for $\alpha_{\mathrm{S} 2}$-casein and to $-204 \mathrm{mV}$ for $\alpha_{\mathrm{S} 1}$-casein at $\mathrm{pH} \mathrm{9,} \mathrm{but} \mathrm{the}$ order of fractions does not change significantly. The isoelectric point increases on average by $1 \mathrm{pH}$ unit. The enhancement of the differences of the electrostatic potential between the casein fractions by ethanol could be employed for the preparation of enriched or purified $\alpha_{\mathrm{S1}}$-casein $[30,78]$.

The evolution of the electrostatic surface potential $\left(\psi_{0}\right)$ of individual casein fractions, or the hypothetical total casein, explains casein solubility quite well as a function of $\mathrm{pH}$ and the dielectric constant of the solvent. It has to be stressed, however, that at $\mathrm{pH}<1$ the molecules have only positive charges and at $\mathrm{pH}>13.5$ they are almost exclusively negatively charged. Within the $\mathrm{pH}$ range between 3 and 9, analysed in this work, the casein molecules have both sorts of charges. For this reason, not only repulsive but also attractive electrostatic interactions exist within the same molecules and between different casein molecules, leading to the formation of casein micelles $[19,22,61,62]$. The state of casein aggregation in sodium caseinate solutions is not very well known. Dalgleish and Law [11] found particle presence of around $100 \mathrm{~nm}$ in water solutions containing $15 \mathrm{mmol} \cdot \mathrm{L}^{-1}$ of $\mathrm{Ca}^{2+}$ for spray-dried, $50 \mathrm{~nm}$ 


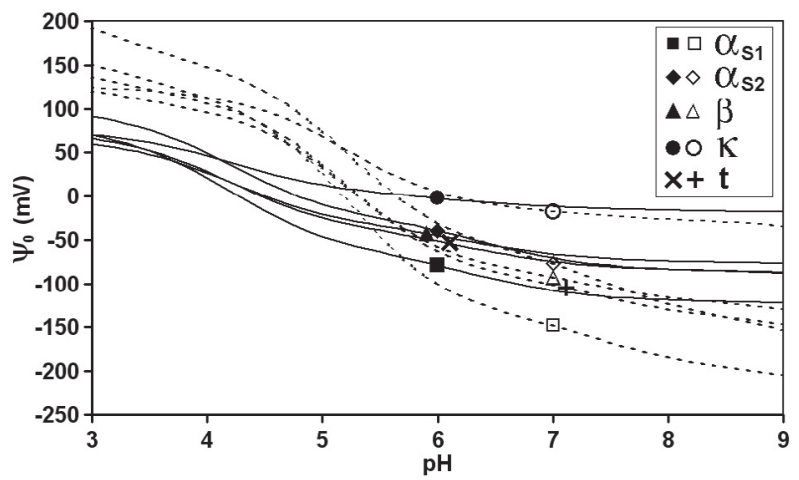

Figure 15. Evolution of the electrostatic surface potential $\left(\psi_{0}\right)$ of principal casein fractions $\left(\alpha_{S_{1}}\right.$, $\alpha_{S_{2}-}, \beta-$ and $\mathrm{K}^{-}$) dissolved in water (solid lines) or in $60 \%(\mathrm{v} / \mathrm{v})$ ethanol (broken lines) as a function of $\mathrm{pH}$. The lines (t) represent total casein.

for roller-dried and $300 \mathrm{~nm}$ for laboratory prepared and freeze-dried sodium caseinate samples. For industrial calcium caseinates dissolved in water, Moughal et al. [44] found the particle size distribution to be bimodal, with the radius of the first peak of around 170-200 $\mathrm{nm}$ and that of the second peak of around 13-17 $\mu \mathrm{m}$. In the absence of calcium ions, the aggregates in the sodium caseinate are too small to be detected by laser methods based on the intensity of the scattered light [11, 44, 74].

\section{CONCLUSION}

Casein solubility is a function of the intermolecular repulsion forces governed by the ionisation process of acidic and amino groups, being a function of $\mathrm{pH}$ and of the solvent's dielectric constant.

Equations describing the ionisation phenomenon, the electrostatic surface potential and the electrostatic surface energy quite satisfactorily represent casein solubility in water and in water ethanol mixtures.

The same equations would be applicable for other proteins and other polar solvents such as, for example, alcohols, amides, amines, esters, glycols, ketones, nitriles and sulphoxides.

A similar approach could be applied to studying the solubility of individual casein fractions and especially of $\alpha_{\mathrm{S} 1}$-casein in neutral and slightly basic solutions and $\alpha_{\mathrm{S}^{-}}$ casein in acidic conditions.

\section{REFERENCES}

[1] Åkerlöf G., Dielectric constants of some organic solvent-water mixtures at various temperatures, J. Amer. Chem. Soc. 54 (1932) 4125-4139.

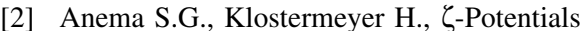
of casein micelles from reconstituted skim milk heated at $120^{\circ} \mathrm{C}$, Int. Dairy J. 6 (1966) 673-687.

[3] Banks W., Muir D.D., Effect of alcohol content on emulsion stability of cream liqueurs, Food Chem. 18 (1985) 139-152.

[4] Banks W., Muir D.D., Wilson A.G., Extension of the shelf life of cream-based liqueurs at high ambient temperatures, J. Food Technol. 16 (1981) 587-595.

[5] Banks W., Muir D.D., Wilson A.G., The formulation of cream-based liqueurs, Milk Ind. 83 (1981) 16,18.

[6] Banks W., Muir D.D., Wilson A.G., Formulation of cream-based liqueurs: a comparison of sucrose and sorbitol as the carbohydrate component, J. Soc. Dairy Technol. 35 (2) (1982) 41-43.

[7] Bingham E.W., Influence of temperature and $\mathrm{pH}$ on the solubility of $\alpha_{\mathrm{s} 1}, \beta$ and $\kappa$-casein, J. Dairy Sci. 54 (1971) 1077-1080.

[8] Chavez M.S., Negri L.M., Taverna M.A., Cuartín A., Bovine milk composition parameters 
affecting the ethanol stability, J. Dairy Res. 71 (2004) 201-206.

[9] Clark D.C., Smith L.J., Influence of alcoholcontaining spreading solvents on the secondary structure of proteins: A circular dichroism investigation, J. Agric. Food Chem. 37 (1989) 627-633.

[10] Dalgleish D.G., Measurement of electrophoretic mobilities and zeta-potentials of particles from milk using laser Doppler electrophoresis, J. Dairy Res. 51 (1984) 425-438.

[11] Dalgleish D.G., Law A.J.R.,. Sodium caseinates - composition and properties of different preparations, J. Soc. Dairy Technol. 41 (1988) 1-4.

[12] Darling D.F., Dickson J., The determination of the zeta potential of casein micelles, J. Dairy Res. 46 (1979) 329-332.

[13] Darling D.F., Dickson J., Electrophoretic mobility of casein micelles, J. Dairy Res. 46 (1979) 441-461.

[14] Davies D.T., White J.C.D., The relation between the chemical composition of milk and the stability of the caseinate complex. II Coagulation by ethanol, J. Dairy Res. 25 (1958) 256-266.

[15] Donnelly W.J., Ethanol stability of casein solutions as related to storage stability of dairy-based alcoholic beverages, J. Food Sci. 52 (1987) 389-393.

[16] Downey W.K., Murphy R.F., The temperature-dependent dissociation of $\beta$-casein from bovine casein micelles and complexes, J. Dairy Res. 37 (1970) 361-372.

[17] Dufour E., Bertrand-Harb C., Haertlé T. Reversible effects of medium dielectric constant on structural transformation of $\beta$-lactoglobulin and its retinal binding, Biopolymers 33 (1993) 589-598.

[18] Dufour E., Robert P., Bertrand-Harb C., Haertlé T., Conformation change of $\beta$-lactoglobulin: An ATR infrared spectroscopy study of the effect of $\mathrm{pH}$ and ethanol, J. Protein Chem. 13 (1994) 143-149.

[19] Evans M.T.A., Irons L., Jones M., Physicochemical properties of $\beta$-casein and some carboxyacyl derivatives, Biochim. Biophys. Acta 229 (1971) 411-422.

[20] Famelart M.H., Hardy M.H., Brulé G., Étude des facteurs d'extraction de la caséine- $\beta$, Lait 69 (1989) 47-57.

[21] Famelart M.H., Lepesant F., Gaucheron F., Le Graët Y., Schuck P., pH-induced physicochemical modifications of native phosphocaseinate suspensions: Influence of aqueous phase, Lait 76 (1996) 445-460.
[22] Farrer D., Lips A., On the self-assembly of sodium caseinate, Int. Dairy J. 9 (1999) 281 286.

[23] Green M.L., Crutchfield G., Density-gradient electrophoresis of native and of rennettreated casein micelles, J. Dairy Res. 38 (1971) 151-164.

[24] Gripon C., Legrand L., Rosenman I., Vidal O., Robert M.C., Boué F., Lysozyme-lysozyme interactions in under- and super-saturated solutions: a simple realation between the second virial coefficients in $\mathrm{H}_{2} \mathrm{O}$ and $\mathrm{D}_{2} \mathrm{O}$, J. Crystal Growth 178 (1997) 575-584.

[25] Guillaume C., Jiménez L., Cuq J.L., Marchesseau S., An original pH-reversible treatment of milk to improve rennet gelation, Int. Dairy J. 14 (2004) 305-311.

[26] Guillaume C., Gastaldi E., Cuq J.L., Marchesseau S., Effect of $\mathrm{pH}$ on rennet clotting properties of $\mathrm{CO}_{2}$-acidified skim milk, Int. Dairy J. 14 (2004) 437-443.

[27] Harvey A.H., Prausnitz J.M., Dielectric constants of fluid mixtures over a wide range of temperature and density, J. Solution Chem. 16 (1987) 857-869.

[28] Hewedi M.M., Mulvihill D.M., Fox P.F., Recovery of milk protein by ethanol precipitation, Ir. J. Food Sci. Technol. 9 (1985) 1123.

[29] Hiemenz P.C., Rajagopalan R., Principles of Colloid and Surface Chemistry, 3rd edn., Marcel Dekker Inc., New York, USA, 1997.

[30] Hipp N.J., Groves M.L., Custer J.H., McMeekin T.L., Separation of $\alpha \beta$ and $\gamma$ casein, J. Dairy Sci. 35 (1952) 272-281.

[31] Horne D.S., Ethanol stability of casein micelles - a hypothesis concerning the role of calcium phosphate, J. Dairy Res. 54 (1987) 389395.

[32] Horne D.S., Ethanol stability, in : Fox P.F. (Ed.), Advanced Dairy Chemistry, vol.1: Proteins, Elsevier Applied Science, London, UK, 1992, pp. 657-689.

[33] Horne D.S., Parker T.G., The pH sensitivity of ethanol stability of individual cow milks, Neth. Milk Dairy J. 34 (1980) 126-130.

[34] Horne D.S., Parker T.G., Factors affecting the ethanol stability of bovine milk. I. Effect of serum phase components, J. Dairy Res. 48 (1981) 273-284.

[35] Horne D.S., Parker T.G., Factors affecting the ethanol stability of bovine milk. II. The origin of $\mathrm{pH}$ transition, J. Dairy Res. 48 (1981) 285-291.

[36] Horne D.S., Parker T.G., Factors affecting the ethanol stability of bovine milk. V. Effect 
of chemical modification of milk proteins, $\mathrm{J}$. Dairy Res. 49 (1982) 449-457.

[37] IDF, Milk. Determination of non-caseinic nitrogen content. Standard 29, Int. Dairy Fed., Brussels, Belgium, 1964.

[38] IDF, Milk. Determination of nitrogen content. Standard 20B, Int. Dairy F., Brussels, Belgium, 1993.

[39] Igarashi Y., Separation of caseins by chemical procedures, Int. Dairy J. 9 (1999) 377378.

[40] Kruif C.G., Tuinier R., Colloidal Interactions. Stabilisation of food colloids by polymers, in: Dickinson E. (Ed.), Food Colloids. Interactions, Microstructure and Processing, The Royal Society of Chemistry, Cambridge, UK, 2005, pp. 61-73.

[41] Lynch A.G., Mulvihill D.M., Effect of sodium caseinate on the stability of cream liqueurs, Int. J. Dairy Technol. 50 (1997) 1-7.

[42] Maubois J.L., Léonil J., Peptides du lait à activité biologique, Lait 69 (1989) 245-269.

[43] Mohammed K.S., Fox P.F., Heat and alcohol-induced coagulation of casein micelles, Ir. J. Food Sci. Technol. 10 (1986) 47-55.

[44] Morr C.V., Functional properties of milk proteins and their use as food ingredients, in : Fox P.F. (Ed.), Developments in dairy chemistry, vol. 1: Proteins, Applied Science Publishers, London, UK, 1982, pp. 375-399.

[45] Moughal K.I., Munro P.A., Singh H., Suspension stability and size distribution of particles in reconstituted, commercial calcium caseinates, Int. Dairy J. 10 (2000) 683-690.

[46] Muir D.D., Cream liqueur manufactureassessment of efficiency of methods using a viscometric technique, Dairy Ind. Int. 52 (1987) 38-40.

[47] Muir D.D., Formulation of a cream liqueur model system for use in coffee, N. Z. J. Dairy Sci. Technol. 23 (1988) 1-9.

[48] Muir D.D., Dalgleish D.G., Differences in behaviour of sodium caseinates in alcoholic media, Milchwissenschaft 42 (1987) 770772.

[49] O'Connel J.E., Fox P.F., Proposed mechanism for the effect of polyphenols on the heat stability of milk, Int. Dairy J. 9 (1999) 523536.

[50] O'Kennedy B.T., Cribbin M., Kelly P.M., Stability of sodium caseinate to ethanol, Milchwissenschaft 56 (2001) 681-684.

[51] Park S.Y., Niki R., Sano Y., Size effects of casein micelles on rennet gels in the presence of $\beta$-lactoglobuline, Int. Dairy J. 9 (1999) 379-380.
[52] Pearce K.N., Moving boundary electrophoresis of native and rennet-treated casein micelles, J. Dairy Res. 43 (1976) 27-36.

[53] Philippe M., Le Graët Y., Gaucheron F., The effects of different cations on the physicochemical characteristics of casein micelles, Food Chem. 90 (2005) 673-683.

[54] Pierre A., Étude de la stabilité du lait à l'alcool. Solubilité du phosphate et du calcium du lait en présence d'éthanol, Lait 65 (1985) 201-212.

[55] Pierre A., Milk stability in ethalonic solutions, J. Dairy Res. 56 (1989) 521-527.

[56] Pierre A., Brulé G., Mineral and protein equilibria between the colloidal and soluble phases of milk at low temperature, J. Dairy Res. 48 (1981) 417-428.

[57] Robitaille G., Britten M., Petitclerc D., Effect of a differential allelic expression of $\mathrm{\kappa}$-casein gene on ethanol stability of bovine milk, J. Dairy Res. 68 (2001) 145-149.

[58] Roefs S.P.F.M., Walstra P., Dalgleish D.G., Horne D.S., Preliminary note on the change in casein micelles caused by acidification, Neth. Milk Dairy J. 39 (1985) 119-122.

[59] Rose D., Relation between micellar and serum casein in bovine milk, J. Dairy Sci. 51 (1968) 1897-1902.

[60] Schaink H.M., Smit J.A.M., Determination of the osmotic second virial coefficient and the dimerization of $\beta$-lactoglobulin in aqueous solutions with added salt at the isoelectric point. Physical Chemistry Chemical Physics 2 (2000) 1537-1541.

[61] Schmidt D.G., Association of caseins and casein micelle structure, in : Fox P.F. (Ed.), Developments in dairy chemistry, vol. 1, Applied Science Publishers, London, UK, 1982, pp. 61-82.

[62] Schmidt D.G., Payens T.A.J., van Markwijk B.W., Brinkhuis J.A., On the subunit of $\alpha_{\mathrm{S}^{-}}$ casein, Biochem. Biophys. Res. Comm. 27 (1967) 448-455.

[63] Silva S.V., Malcata F.X., Caseins as source of bioactive peptides. Review, Int. Dairy J. 15 (2005) $1-15$.

[64] Smith R.L., Jr., Lee S.B., Komori H., Arai K., Relative permittivity and dielectric relaxation in aqueous alcohol solutions, Liq. Phase Equil. 144 (1998) 315-322.

[65] Sommer H.H., Binney T.H., A study of the factors that influence the coagulation of milk in the alcohol test, J. Dairy Sci. 6 (1923) 176197.

[66] Swaisgood H.E., Chemistry of the caseins, in: Fox P.F.(Ed.), Advanced dairy chemistry, 
vol.1, Proteins, Elsevier Science Publishers Ltd., London, UK, 1992, pp. 63-110.

[67] Swaisgood H.E., Protein and amino acid composition of bovine milk, in: Jensen R.G. (Ed.), Handbook of Milk Composition, Academic Press, San Diego, USA, 1995, pp. 464-468.

[68] Szereniewicz M., Kiwk A., Kietczewska K., Ethanol-induced changes in proteins and some mineral compounds of milk, Polish J. Food Nutr. Sci. 8/49 (1999) 27-38.

[69] Towler C., Conversion of casein curd to sodium caseinate, N. Z. J. Dairy Sci. Technol. 11 (1976) 24-29.

[70] Towler C., Roller-dried sodium caseinate, N. Z. J. Dairy Sci. Technol. 11 (1976) 140-141.

[71] Towler C., The manufacture and reconstitution characteristics of granular sodium caseinate, N. Z. J. Dairy Sci. Technol. 13 (1978) 71-76.

[72] Trémillon B., Électrochimie analytique et réactions en solution. Tome 1, Masson, Paris, France, 1993.

[73] Vuillemard J.C., Gauthier S., Paquin P., Les ingrédients à base de protéines laitières: Obtention, propriétés et utilisation, Lait 69 (1989) 323-351.
[74] Walstra P., Physical Chemistry of Foods, Marcel Dekker Inc., New York, USA, 2003.

[75] Walstra P., Jenness R., Dairy Chemistry and Physics, John Wiley and Sons, New York, USA, 1984.

[76] Zadow J.G., The rate of addition of alcohol has a major effect on the alcohol stability of skim milk, Aust. J. Dairy Technol. 48 (1993) 38-39.

[77] Zadow J.G., Alcohol-mediated temperatureinduced reversible dissociation of the casein micelle in milk, Aust. J. Dairy Technol. 48 (1993) 78-81.

[78] Zittle C.A., Custer J.H., Purification and some of the properties of $\alpha_{\mathrm{s}}$-casein and $\kappa$ casein, J. Dairy Sci. 46 (1963) 1183-1188.

[79] Zittle C.A., Pepper L., Influence of hydrogen and calcium ion concentrations, temperature, and other factors on the rate of aggregation of casein, J. Dairy Sci. 41 (1958) 1671-1682.

[80] Zittle C.A., Cerbulis J., Pepper L., Della Monica E.S., Preparation of calcium-sensitive $\alpha$-casein, J. Dairy Sci. 42 (1959) $1897-$ 1902. 